\title{
THE ECONOMIC VALUE OF HYDROLOGICAL SERVICES IN MENDALAM SUB WATERSHED, KAPUAS HULU REGENCY, WEST KALIMANTAN, INDONESIA
}

\author{
Emi Roslinda ${ }^{1 *}$ and Yuliantini ${ }^{1}$ \\ Received: 13 August 2012, Accepted: 4 December 2013
}

\begin{abstract}
Forest ecosystem supports almost all of the needs of human being through its contribution of tangible and intangible values. Currently, the intangible values have gained less attention than the tangible values that cause underestimation of the total value of the forest conversion into other more tangibly profitable usages, and miss-management of the forest. One of the important intangible values is the hydrological value that has been hardly calculated until now. This paper studies the intangible values of water for household, transportation, agriculture and fishing in Mendalam Sub Watershed, Kalimantan. The economic values calculated based on market prices, opportunity costs and consumer's surplus methods. The results showed that based on the opportunity cost method the economic values of the hydrological services was about Rp 8,043,706,237.50 per year. Meanwhile, the economic values of the hydrological services based on the consumer's surplus method gave lower value than the former method, i.e. Rp 8,031,351,664.60 per year. This study showed that the economic value of the hydrological services was very high, which has not been included in the calculation yet. However, without trees there would be no forest and all other values included water value would not be exist. Consequently, current forest management should put forest ecosystem as important to consider.
\end{abstract}

Keywords: Intangible value, hydrological services, forest ecosystem, Mendalam, sub watershed

\begin{abstract}
ABSTRAK
Ekosistem hutan mampu memenuhi hampir seluruh kebutuhan manusia melalui kontribusi nilai-nilai yang bersifat tangible dan intangible yang dimilikinya. Namun, nilai intangible yang dimiliki hutan kurang mendapat perhatian dibanding nilai tangible hutan. Hal ini berakibat pada estimasi yang rendah terhadap nilai total yang dimiliki ekosistem hutan sehingga menyebabkan terjadinya konversi ekosistem hutan kepada penggunaan lain yang dianggap lebih menguntungkan dan terjadi kesalahan dalam pengelolaan ekosistem hutan. Salah satu nilai intangible hutan yang penting adalah nilai hidrologis. Sampai saat ini, nilai jasa hidrologis hutan sulit untuk dihitung. Dalam penelitian ini nilai intangible dari air untuk kebutuhan rumah tangga, transportasi, pertanian dan perikanan di Sub DAS Mendalam telah dilakukan. Nilai ekonomi dihitung menggunakan metode nilai pasar, biaya kesempatan dan surplus konsumen. Hasil penilaian menunjukkan berdasarkan biaya kesempatan nilai hidrologi adalah Rp 8.043.706.237,50 per tahun. Sementara nilai hidrologi berdasar surplus konsumen adalah Rp 8.031.351.664,60 per tahun, berarti lebih rendah dibanding metode biaya kesempatan. Penelitian ini menunjukkan bahwa nilai ekonomi jasa hidrologi hutan sangat tinggi, yang mana belum dimasukkan dalam perhitungan nilai ekonomi ekosistem hutan sehingga menimbulkan salah pengelolaan ekosistem hutan. Namun, perlu diingat bahwa tanpa adanya pohon tidak akan ada ekosistem hutan dan semua nilai ekonomi hutan yang terkandung di dalamnya. Konsekuensinya adalah, pengelolaan hutan saat ini dan masa mendatang perlu perhatian lebih lanjut mengenai ekosistem hutan.
\end{abstract}

Kata kunci: Nilai intangible, jasa hidrologis, ekosistem hutan, Mendalam, sub DAS

\footnotetext{
${ }^{1}$ Faculty of Forestry, Tanjungpura University, Jl. Ahmad Yani Pontianak, West Kalimantan - Indonesia

* Corresponding Author : eroslinda71@gmail.com
} 


\section{INTRODUCTION}

Forest has a variety of biophysical components; ecological functions that can provide environmental services; cultural and social functions and economic values for the people living around the forest. So far, the economic value of the forest is generally assessed from the value of timber production only, while the value of the environmental services of the forest (for example: water) is underestimated or not estimated at all because it is considered as public goods. Environmental services of the forest are non-tangible benefits which are difficult to quantify and giving rise to externalities. According to Hartwick and Oliver (1998), public externalities occur when public goods are consumed without proper payment. To suppress these externalities there is a need to make a valuation of forest values.

Economic valuation can be defined as the attempt to assign quantitative values to the goods and services provided by the ecosystem. The economic value of any goods or services is generally measured in terms of what we are willing to pay for the commodity less what it costs to supply it. Where an environmental resource simply exists and provides us with products and services at no cost, then it is our willingness to pay alone that describes the value of the resource in providing such commodities, whether or not we actually make any payment.

Environmental services are supplied by the ecosystem, one of which is the function of the hydrology, which provide benefits for humans.

Hydrological services are one of the economic values of the forests which until now have not been taken into account because there is no market price for these services. It is necessary to make an economic valuation of the environmental services generated by the forest. Economic valuation is required as a means for decision making in forest management (Bahruni, 2008; Syaukani, 2005; Widada, 2004; Barbier et al., 1997; Munasinghe et al., 1994).

However, valuation is only one element in the effort to improve forest management and services. Economic valuation may help to inform management decisions, but only if decision-makers do understand the overall objectives and limitations of the valuation. The objective of the valuation of ecosystem services is to indicate generally the overall economic efficiency of the various competing uses of the functions of a particular ecosystem. The underlying assumption is that ecosystem resources should be allocated to those uses that yield an overall net gain to the society, as measured through valuation in terms of the economic benefit of each use adjusted by its costs (Kumar and Kumar, 2008). The objective of this study is to determine the economic value of the hydrological services in Mendalam Sub Watershed.

\section{METHODOLOGY}

The research was conducted by using the survey method. Mendalam Sub Watershed was purposely selected comprising of 3 valleys and 9 hamlets. A total number of 120 respondents, 40 families in each valley, from small local communities were randomly selected. Collection of data and information was done by using the questionnaire interview technique.

The economic values were calculated based on market prices, opportunity costs and consumer's surplus methods (Pearce and Moran, 1994). Market price method uses the prices of goods and services that are bought and sold on the commercial markets to determine the value of an ecosystem service. This method only takes into account use-values and marketed goods or services that have an actual price. In this research opportunity costs method is based on the productivity method. The productivity method measures the contribution of a non-market ecosystem service that has on a marketed commodity. This method is most useful in cases where a resource is a perfect substitute for another input for production and in cases where the producers are the only ones to benefit from changes in quantity or quality of the resource, and consumers are not affected. 
Table 1. Forest types in Mendalam Sub Watershed

\begin{tabular}{llr}
\hline No. & Forest Types & Area (Ha) \\
\hline 1. & Shrub swamp (Belukar rawa) & 18,185 \\
2. & Mixed upland forest (Hutan lahan kering campuran) & 127,364 \\
3. & Secondary upland forest (Hutan lahan kering sekunder) & 37,750 \\
4. & Secondary swamp forest (Hutan rawa sekunder) & - \\
5. & Settlement (Pemukiman) & - \\
6. & Mix dryland farming (Pertanian lahan kering campur) & 55 \\
7. & Shrub (Semak/Belukar) & - \\
8. & Water (Tubuh air) & 518 \\
\hline
\end{tabular}

Consumer's surplus method is based on the demand function from goods and services by measuring the consumer's surplus after the application of a change in the production or price, the value can be determined.

This research is intended to illustrate the intangible values from the forest especially the hydrological ones that could give a lot of benefits for the communities, i.e.: for household, agriculture, fishing and transportation. The benefits depend on the presence of the existing watershed. If the watershed is in good condition, the benefits will be felt by the surrounding communities and downstream areas.

\section{RESULT AND DISCUSSION}

Table 1 presents the forest types of Mendalam Sub Watershed, one of the units belongs to the hydrological system of Betung Kerihun National Park.

Along the Mendalam Sub Watershed, there are 9 hamlets in 3 valley administrations; the composition of the communities can be seen in Table 2. There are 4 tribes living together, i.e: Kayaan Mendalam, Ariung Mendalam (Taman semangkok), Melayu Sambus and Bukat. All of the communities use water from the river for their every day's needs.

In the everyday's life the people practice shifting cultivation in the drylands. In the wetlands the ethnic Malays, Taman and Kayaan

Table 2. Name of hamlets and the number of inhabitants in Mendalam Sub Watershed

\begin{tabular}{|c|c|c|c|}
\hline No & Valley/hamlet & Number of people & Number of household \\
\hline \multirow[t]{4}{*}{1.} & Datah diaan valley & & \\
\hline & Nanga hovat & 144 & 35 \\
\hline & Uma' suling & 280 & 64 \\
\hline & Pagung & 376 & 106 \\
\hline \multirow[t]{4}{*}{2.} & Padua mendalam valley & & \\
\hline & Teluk telaga & 706 & 152 \\
\hline & Tanjung karang & 222 & 57 \\
\hline & Lung miting & 311 & 74 \\
\hline \multirow[t]{5}{*}{3.} & Tanjung jati valley & & \\
\hline & Semangkok & 342 & 73 \\
\hline & Nanga sambus & 714 & 175 \\
\hline & Tanjung jati & 1702 & 143 \\
\hline & Total & 4770 & 883 \\
\hline
\end{tabular}


undertake gardening activities, while ethnic Bukat still follow the tradition of shifting cultivation of dry land farming and very rarely plant vegetables so it is unlikely that they will buy vegetables from wealthier farms of the tribal villages downstream Bukat. The Bukat more frequently hunt animals in the forest. Taman tribal's women, in addition to farming activities, also known for their skills as craftsmen (handicrafts). In other activities, at the Putussibau market they often sell products from growing crops in the field or vegetables and fruits which they collect from the forest. This farming and gardening system are two elements in the society of Taman and Kayaan as a result of their interaction with the surrounding nature which they have done for generations.

This interaction has gradually formed a legacy of tradition that is believed to have noble values. As an example every year a form of cultural/customary tradition is still being held to give due thanks to the Almighty for the crops they earn. The event is known as "Dange" or "Pamole "Beo" (Tamambaloh Dayak language) and also is commonly known by the whole Dayak tribe in West Kalimantan under the name "Naik Dango" (in the Dayak language Kanayant). In this activity their culture is visible presented in specific forms such as: dance, repertoire of oral literature, the splendour of the motive shield/ karawit and tattoos, accessories of custom clothing, the uniqueness of the motive mask "Hudo" and the ceremonial procession, all of it is loaded with the meaning of the life.

The benefits of the ecosystem services from the forests were identified as the water obtained by the people for their household in Mendalam Sub Watershed, the water for agriculture, the water for fishing and the water for transport. In Mendalam Sub Watershed the following variables affect the water consumption: number of family members (X2) and education level (X5). Using the method of Marshall the demand curve equation will be as follows:

$\mathrm{Y}=390.88-7.83 \mathrm{X} 1+1.815 \mathrm{X} 2-1.265 \mathrm{X} 3-$ $24.845 \mathrm{X} 4+179.260 \mathrm{X} 5-1.191 \mathrm{X} 6$
Determination of economic value of watershed services that include the total willingness to pay, expenses, and consumer's surplus is based on the willingness of consumers to sacrifice to consume the goods or services obtained from watershed services. Determination of the economic value of water was done by using the demand curve of Marshall with the following stages:

1. Model

$$
\begin{aligned}
\mathrm{Y}= & 390.88-7.83(\mathrm{X} 1)+1.815(\mathrm{X} 2)- \\
& 1.265(\mathrm{X} 3)-24.845(\mathrm{X} 4)+179.260 \\
& (\mathrm{X} 5)-1.191 \text { (X6) }
\end{aligned}
$$

2. Intercept $(\beta 0)$

$$
\begin{aligned}
\mathrm{Y}= & 390.88-7.83(\mathrm{X} 1)+1.815(1.4)- \\
& 1.265(43.10000)-24.845(2.6750)+ \\
& 179.260(5.7083)-1.191(70.0000) \\
\mathrm{Y}= & 390.88-7.83(\mathrm{X} 1)+2.541-54.5215- \\
& 66.460+1023.269-83.37 \\
\mathrm{Y}= & 390.88-7.83 \mathrm{X} 1+821.4585 \\
\mathrm{Y}= & 121.3385-7.83 \mathrm{X} 1
\end{aligned}
$$

3. Infers

$$
\begin{aligned}
& \mathrm{Y}=1212.3385-7.83 \mathrm{X} 1 \\
& X_{1}=\frac{1212.3385-Y}{7.8} \\
& \mathrm{X} 1=154.838-0.1277 \mathrm{Y}
\end{aligned}
$$

4. Willingness to pay

(1) $U=\int_{0}^{Y} f(Y) \delta Y$

(2) $U=\int_{0}^{Y} f(154.838-0.1277) \delta \mathrm{Y}$

(3) $\left.U=154.838 Y-\frac{0.1277}{2} Y^{2}\right]_{0}^{1198.3284}$

(4) $U=185546.7728-(0.06385 \times 1435990.954)$

(5) $\mathrm{U}=185546.7728-91688.02243$

(6) $\mathrm{U}=93858.75037$ 
Table 3. Economic value of water for household needs

\begin{tabular}{lrrr}
\hline Economic value & $\begin{array}{r}\text { Sample } \\
\text { (Rp/people/year) }\end{array}$ & $\begin{array}{r}\text { Population } \\
\text { (people) }\end{array}$ & $\begin{array}{r}\text { Total } \\
\text { (Rp/year) }\end{array}$ \\
\hline Willingness to pay & $93,858.75$ & 4,770 & $447,706,237.50$ \\
Value of sacrifice & $2,170.77$ & 4,770 & $10,354,572.90$ \\
Consumers' surplus & $91,687.98$ & 4,770 & $437,351,664.60$ \\
\hline
\end{tabular}

Table 4. Economic valuie of agriculture

\begin{tabular}{llll}
\hline No & Subject & \multicolumn{1}{c}{ Calculation } & Total \\
\hline 1. & Economic value & (number of household x number of harvest per year & Rp 1,584,000,000 \\
of agriculture per & x price of rice) - (number of household x production \\
year & $\begin{array}{l}\text { cost) }(1,584 \times 300 \times \mathrm{Rp} \mathrm{10,000,-)}-(1,584 \times \mathrm{Rp} \\
\end{array}$ & \\
\hline
\end{tabular}

5. $\mathrm{X} 1$ at $\mathrm{Y}$

$\mathrm{X} 1=154.838-0.1277 \mathrm{Y}$

$\mathrm{X} 1=154.838-0.1277(1198.3284)$

$\mathrm{X} 1=154.838-153.0265$

$\mathrm{X} 1=1.8115$

6. The value of sacrifice (NA)

$\mathrm{NA}=\mathrm{X} 1 \times \mathrm{Y}$

$\mathrm{NA}=1.8115 \times 1198.3284$

$\mathrm{NA}=2170.771897$

7. Consumer's Surplus

Consumer's surplus $=$ Willingness to pay value of sacrifice

$$
\begin{aligned}
& =93858.75-2170.77 \\
& =91687.98
\end{aligned}
$$

8. Economic Value

Summary of calculation of total economic value of water use of households is presented in Table 3 below. Calculation was based on the value of the total willingness to sacrifice, value of the sacrifice, and value of the consumer's surplus to the needs of water users of the entire population of all households. It was done by extrapolating the values with the population of Mendalam Sub-basin which is consisting of 4,770 people.

The results showed that value of the average willingness to pay, the value of the sacrifice, and the consumer's surplus was Rp 93,858.75/ people/year, Rp 2,170.77/people/year and Rp 91,687.98/people/year, respectively. The value of water was higher when compared with the results of research in Gunung Halimun National Park (Widada, 2004), where willingness to pay was Rp 23,774.8/people/year, value of sacrifice was Rp 5,294.7/people/year and consumers'

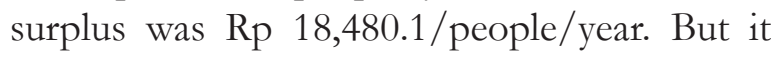
was far smaller if compared with the results of the research in Gunung Walat Educational Park (Roslinda, 2002), where the value for willingness to sacrifice was Rp 295,679.25/people/year, value of sacrifice was Rp 2,196.81/people/year and consumer's surplus was Rp 293,482.49/ people/year. This may have happened because the need of water for households are different from place to place.

Economic value of agriculture (especialy from ladang) was calculated using the market price method. The shifting cultivation area was used free by farmers. In the calculation of production costs land was included and all the activities carried out during the process of farming were included i.e. clearing, cutting, slashing, burning, clean up burning, planting, removing grass, crop, save and rice rotation (mengisar padi). All activities are carried out during 6-7 months and people worked together.

One hectare of land is usually farmed by a family of 4-5. If one assumes a fruit farm with an area of 1 hectare, farmed by 5 people, than if one hectare of land is valued at $R p 1,000,000$. 
Table 5. Economic value of fisheries

\begin{tabular}{llll}
\hline No & Subject & Calculation & Total \\
\hline 1. & $\begin{array}{l}\text { Economic value of } \\
\text { fishing per year }\end{array}$ & $\begin{array}{l}\text { (number of household x amount of fish/day x } \\
\text { number of day per year x fish price) } \\
\end{array}$ & $\begin{array}{l}(1,584 \times 1 \times 289,600,000 \\
\end{array}$ \\
\hline
\end{tabular}

Table 6. Economic value of transportation

\begin{tabular}{|c|c|c|c|}
\hline No & Subject & Calculation & Total \\
\hline 1. & $\begin{array}{l}\text { Economic value of } \\
\text { transportation }\end{array}$ & $\begin{array}{l}\text { (number of people } \times \text { number of day per year } \\
\times \text { ticket price } \times \text { number of transport) }- \text { (cost of } \\
\text { premium) } \\
(40 \times 365 \times \operatorname{Rp} 20,000 \times 7)-(40 \times \operatorname{Rp~} 10,000 \times x \\
365 \times 7)\end{array}$ & Rp 1,022,000,000 \\
\hline
\end{tabular}

Table 7. Summary of calculations of the hydrological value based on the willingness of sacrifice (opportunity cost) and consumer's surplus

\begin{tabular}{llrr}
\hline \multirow{2}{*}{ No } & Hydrological value & \multicolumn{2}{c}{ Total value (Rp/year) } \\
& & Opportunity Cost & \multicolumn{1}{c}{ Consumer's Surplus } \\
\hline 1. & Household & $447,706,237.50$ & $437,351,664.60$ \\
2. & Agriculture & $1,584,000,000.00$ & $1,584,000,000.00$ \\
3. & Fishing & $4,990,100,000.00$ & $4,990,100,000.00$ \\
4. & Transportation & $1,022,000,000.00$ & $1,022,000,000.00$ \\
\hline Total & & $8,043,706,237.50$ & $8,031,351,664.60$ \\
\hline
\end{tabular}

the operational cost for working in 10 phases is calculated at Rp 20,000 per person per phase of labor, then it would require a fee of $\operatorname{Rp} 1,000,000$ $+(\operatorname{Rp} 20,000 \times 5 \times 10)=\operatorname{Rp} 2,000,000$ per-ha/ household/year. Based on this assumption, the value of agriculture is shown in Table 4.

Economic value of fishing was also calculated with the market price method. Communities in Mendalam Sub Watershed generally catch fish every day to meet their daily food needs. The types of fish frequently caught are: semah, jelawat, tengadak and rock fish.

From interviews we gathered that the number of fish they can catch vary, depending on luck and natural factors. In general, fishing activities are conducted to meet the needs of sehar-day. The average person of a household is able to catch 1-2 $\mathrm{kg}$ of each type of fish every day. The fish is usually caught not for sale but for home consumption only.
Calculation of the economic value of fishing was done by using the fish type that had the lowest value among the fish types. The fish used in the calculation was a type of rock fish at $\mathrm{Rp}$ $10,000 / \mathrm{kg}$.

The value of income has to be reduced by capital and other costs (equipment such as: net $\operatorname{Rp} 200,000 /$ lifetime of 4 years; trawl Rp 50,000/lifetime of one year; rope nets Rp 10,000 per roll; rope trawl USD 10,000 per roll; rock netting Rp 3,000 per piece). Two rolls per year are needed to rope nets; to rope trawl also requires 2 rolls per year. Rope trawl and nets are usually used to patch up broken straps. Usually 20 pieces of stone nets are needed each year. Capital and equipment costs per year are Rp 200,000/family/year. Based on above assumptions the economic value of fishing can be seen in Table 5 . 
Economic value of transportation was calculated using market prices. Almost all communities in Mendalam Sub Watershed use river transportation, though there are regular public transportation in Pagung, Uma' Suling, and Teluk Telaga hamlets. Besides communities in Mendalam Sub Watershed commonly have a speed boat for their own transportation to go to other valley. Based on assumptions and data, economic value of transportation can be seen in Table 6. In summary the economic value of water used by communities in Mendalam SubWatershed can be seen in Table 7 .

Water used by communities is originating from the Betung Kerihun National Park, which among other functions serves as a protector and guardian of the water system. The consumer's surplus from the use of water was calculated at Rp 437,351,664.60 per year, and the sacrifice value for the society to get this water is estimated at $\mathrm{Rp} 10,354,572$ per year. The value of consumer's surplus is the value of the benefits from the forest ecosystem services that is still often ignored so that the value of forests is often estimated much lower than the true value of what it can generate.

Based on the values that were calculated, it became obvious that the value of the environmental services generated by the forest ecosystem is not often counted, so that the applied forest management does not pay attention to this aspect. As a result, the value of the forest ecosystem is lower than its actual value. Furthermore, forest ecosystem is mismanaged and forest ecosystem was converted to other ecosystem which was considered providing a higher value.

Environmental services are benefits that people obtain from the ecosystem; Paruelo (2012) concluded that ecosystem services are an anthropogenic concept, in the absence of people there are no services (Bennett et al., 2009). Therefore local stakeholders' perception is critical for assessment and management of ecosystem services (Kijazi and Kant, 2010; Vihervaara et al., 2012).
The economic valuation studies are giving the potential values that can be derived from the environmental services of the forests which are intangible benefits. Nurrochmat et al. (2010) states that the environmental services of forests are a function of the water and carbon sinks, which are likely to be recognized in the near future. The function of the water (hydrological) can be of economic value through incentive mechanisms upstream and downstream (Nugroho and Kartodihardjo, 2009; Nurfatriani, 2008). Therefore hydrological values obtained from this research may be even greater if the mechanism can be applied.

The economic value of hydrological services was very high; it was derived from the forest; however, without trees there will be no forests and thus all other values included water value may not exist. Forests have long been recognized as the main ecological construction and restoration means for their multiple ecosystem services (Deal et al., 2012). These services have different spatial-temporal scale characteristics and corresponding different stakeholders. Consequently, the management of the forest ecosystem needs further consideration to make rational management decisions, depending on local conditions, needs and underpinning ecosystem processes.

\section{CONCLUSION}

The results showed that based on the opportunity costs the economic values of hydrological services was estimated at $\mathrm{Rp}$ $8,043,706,237.50$ per year. Meanwhile, the economic values of hydrological services based on the calculation of consumer's surplus method gave a somewhat less value than the former calculation, i.e. Rp 8,031,351,664.60 per year.

The economic value of hydrological services was very high; it was derived from the forest; however, without trees there will be no forest and all other values included water value may be non-existing. Based on the values that were calculated, it became obvious that the value of 
the environmental services generated by the forest ecosystem is not often counted, so that the selected forest management does not pay attention to this aspect. As a result, the value of the forest ecosystem is lower than its actual value. Consequently, forest ecosystem is mismanaged and forest ecosystem was converted to other ecosystem which was considered providing a higher value. It is necessary that the current management of the forest ecosystem needs further consideration to make rational management decisions, depending on local conditions, needs, and underpinning ecosystem processes.

\section{REFERENCES}

Bahruni. (2008). Pendekatan sistem dalam pendugaan nilai ekonomi total ekosistem hutan: studi kasus butan alam produksi bekas tebangan (PhD Thesis). Institut Pertanian Bogor.

Barbier E.B., Acreman, M. C., \& Knowler, D. (1997). Economic Valuation of Wetlands: A Guide for Policy Makers and Planners. Gland, Switzerland: Ramsar Convention Bureau.

Bennett, E. M., Peterson, G. D., \& Gordon, L. J. (2009). Understanding relationships among multiple ecosystem services. Ecology Letters, 12(12), 1394-1404.

Deal, R. L., Cochran, B., \& LaRocco, G. (2012). Bundling of ecosystem services to increase forestland value and enhance sustainable forest management. Forest Policy and Economics, 17, 69-76.

Hartwick, J. M., \& Olliver, N. D. (1998). The Economics of Natural Resources Use. Massachussetts: Addison - Wesley Educational Publisher Inc.

Kijazi, M. H., \& Kant, S. (2010). Forest stakeholders' value preferences in Mount Kilimanjaro, Tanzania. Forest Policy and Economics, 12(5), 357-369.

Kumar, M., \& Kumar, P. (2008). Valuation of the ecosystem services: A psycho-cultural perspective. Ecological Economics, 64(4), 808819.

Munasinghe, M. (Ed.). (1993). Environmental Economics and Natural Resource Management.
Washington DC., USA: World Bank and CIDIE.

Nugroho, B., \& Kartodihardjo, H. (2009). Kelembagaan PES. In Makalah pada Lokakarya Payment on Environmental Services (PES): Pengarusutamaan Imbal Jasa Lingkungan di Indonesia: Trend an Dinamikanya. Bogor, 3-4 Agustus 2009.

Nurfatriani, F. (2008). Merealisasikan pembayaran jasa lingkungan: belajar dari pengalaman di berbagai lokasi. Info Sosial Ekonomi Kebutanan, 1(8), 39-50.

Nurrochmat, D. R., Solihin, I., Ekayani, M., \& Hadianto, A. (2010). Neraca Pembangunan Hijau: Konsep dan Implementasi Bisnis Karbon dan Tata Air di Sektor Kebutanan. Bogor: IPB Press.

Paruelo, J. M. (2012). Ecosystem services and tree plantations in Uruguay: A reply to Vihervaara et al. (2012). Forest Policy and Economics, 22, 85-88. doi:http://dx.doi.org/10.1016/j. forpol.2012.04.005

Pearce, D., \& Moran, D. (1994). The Economic Value of Biodiversity. London: Earthscan Publication Ltd. Retrieved from http://books. google.co.id/s?id=RdH6DRZY0KIC\&pri $\mathrm{ntsec}=$ frontcover\&hl $=\mathrm{id} \&$ source $=\mathrm{gbs} \_\mathrm{ge}$ summary_r\&cad $=0 \# \mathrm{v}=$ onepage $\& \mathrm{q} \& \mathrm{f}=$ false

Roslinda, E. (2002). Nilai Ekonomi Hutan Pendidikan Gunung Walat dan Kontribusinya terhadap Masyarakat Sekitar (PhD Thesis). Institut Pertanian Bogor.

Syaukani, H. R. (2005). Pengembangan kebijakan daerah bagi pengelolaan kawasan konservasi (Studi kasus Taman Hutan Raya Bukit Suharto) (PhD Thesis). Insitut Pertanian Bogor.

Widada. (2004). Nilai Ekonomi dan Pemanfaatan Taman Nasional Gunung Halimun Bagi Masyarakat (PhD Thesis). Institut Pertanian Bogor. 